\title{
Introduction: Contemporary (Debates on) Political Theatre
}

Paola Botham

Political theatre today is in a curious position vis-à-vis theatre scholarship. On the one hand, there are strong signs of a renewed interest in this kind of practice, after the many postCold War dismissals proved too hasty. On the other, habitual expectations about what a political play or performance is and what it can do have been relentlessly questioned, with revised parameters emerging. All six chapters in this section put forward valuable contributions to the current dialogue using novel frameworks and fresh case studies that even if the temptation to generalise is duly resisted - offer numerous pixels in a composite picture of political theatre for the twenty-first century. This introduction aims at gathering some of these ideas and placing them alongside other recent interventions in an academic exchange that is still far from reaching settled conclusions.

In The Contemporary Political Play: Rethinking Dramaturgical Structure, a book that seeks to redefine political theatre in Britain, Sarah Grochala begins from a comprehensive premise, asserting that stage pieces can "function politically on a number of different levels: their ostensibly political content; their creator's political intentions; their political function; the political context of their production; the politics of their mode of production; by challenging or confirming their audience's beliefs; and the politics of the structure that make up their form" (11). Although she eventually focuses on the final element, the "politics of form" (22), which has become contested territory (see below), the attempt to consider all different factors constitutes a productive opening for the debate.

The wide-ranging perspective just outlined is precisely where this section starts, with Bérénice Hamidi-Kim's spirited reassessment of the state of political theatre in France from what she terms a 'socio-aesthetic' methodology, that is, one that accounts not only for actual artistic objects but also for the "social environment in which they are produced, circulated and received". Such an approach, Hamidi-Kim emphasises, also allows an inspection of "the political ambitions underpinning theatrical works", where she discovers conspicuous examples of ideological blind spots. This issue of authorial intention - the second item on Grochala's list - is worth highlighting, as its currency has been restored following a long period when it fell "out of fashion" (Grochala 8) in literature and theatre criticism. ${ }^{1}$

\footnotetext{
${ }^{1}$ More recently, the pervasiveness of Rancièrian thought appears to have exacerbated what Emine Fişek calls the "disavowal of political intention" (358) in theatre theory and practice. Some of Jacques Rancière's claims are briefly discussed below.
} 
Grochala's justification for it in the context of political theatre is convincing enough: "if political theatre were defined exclusively in terms of theatre that can be empirically proven to have had a direct political impact, the field of study would be very small indeed" (9).

As if taking up the aforementioned challenge, Madli Pesti's essay in this collection explores the work of the acclaimed Estonian ensemble Theatre NO99 through the lens of the 'theatrical event' (see Sauter). This implies extending the scope of analysis from text and performance to both the carefully orchestrated public preambles the Tallinn-based troupe was famous for and the actual influence some of its productions arguably had on Estonia's political life. Like Grochala, Pesti proposes a broad set of criteria whereby a play can be deemed 'political', comprising thematic, ideological, aesthetic and functional principles. The last measure inevitably contains the thorny question of whether theatre is able to trigger progressive change in society, and the verdict on Theatre N099 is mixed. While the company's creation of a fictional political party in Ühtne Eesti (Unified Estonia, 2010) has been credited with a snowballing effect that resulted, among other things, in the founding of a real pro-transparency civic movement, the 2015 political musical Savisaar - Pesti's main case study - might have unwittingly increased the electoral tally of the controversial politician cited in the title.

Bridging Hamidi-Kim's and Pesti's chapters is Aneta Głowacka's dissection of political theatre in Poland, a country whose theatrical landscape is akin to that of France according to Hamidi-Kim but which shares its communist past with the Republic of Estonia. After a panoramic overview of Polish political theatre in the twentieth century, Głowacka concentrates on three contemporary practitioners - Monika Strzępka, Paweł Demirski and Jan Klata - who have revitalised the old 'plebeian' heritage of comedy as an artistic strategy for subversion, angering the nation's long-established arbiters of theatrical taste in the process. Common features identified by Głowacka in several waves of post-communist political theatre are "a disregard for [...] convention and tradition" and "an appetite for reinterpreting classical texts by placing them in the present". Both these iconoclastic traits can be located today without much effort in other geographic areas, including those where past political horrors have come from the opposite end of the ideological spectrum. I am referring to Latin America and, more specifically, Chile, which is the setting of the fourth essay in this section (and my own place of birth).

In consonance with the alliance between theatre and civil society discussed by Pesti in relation to NO99's Ühtne Eesti, Camila González Ortiz coins the term 'Citizens' Turn' to designate the synergy between the rise of social movements in Chile from 2006 and a new 
generation of theatre artists, both of which have been mobilised by the shortcomings of the restored democratic system that followed Augusto Pinochet's right-wing military regime (1973-1990). Among several companies and playwrights who are highly sceptical of "the neoliberal processes of modernisation effected during the dictatorship, as well as the policies of the post-dictatorship governments and the behaviour of the political class in general", the author singles out Chilean collective La Re-sentida. Their "visceral, radical and insolent" tactics, González Ortiz claims, amount to a 'poetics of the literal' that rejects metaphor initially developed under censorship and violence - as the preferred vehicle for political theatre. Similarly, Głowacka and Pesti report that the "allusiveness" of political plays, born of necessity during communism, has been replaced by a more direct and at times uncomfortable theatrical language.

Writing about China, where the Communist Party still rules while, paradoxically, global capitalism advances towards 'hypermodernity' (see Lipovetsky), Wei Zheyu notes a comparable directness in the ethos of Grass Stage, a non-professional company that preserves its independence by surviving without state sponsorship or commercial revenue. Taking its cue from 'people's theatre' models in Asia and Latin America - Augusto Boal's Theatre of the Oppressed in particular - this group attributes special importance to the interaction with audiences, both during and after performances. For Wei, Grass Stage's devised productions, made for touring and often performed in non-theatre spaces, promote a frank and necessary dialogue about the local consequences of globalisation. In the case of World Factory (2014), a Chinese-British collaborative project, spectators are confronted with the precarious situation of migrant workers in contemporary China, the parallels that can be drawn with working conditions in England after the Industrial Revolution, and the environmental perils of large-scale manufacturing today.

Inviting audiences to think 'towards' change is also key for Andy Smith, whose pondering of his own 'dematerialised theatre' close this section and the volume as a whole. Although inspired by the less direct, more evocative character of conceptual art, Smith's practice chimes with the accessibility and portability of Grass Stage's low-budget performances. ${ }^{2}$ Accordingly, 'lightness' is one of five propositions he links to his version of political theatre, the others being 'theatreness', 'togetherness', 'presentness' and 'hopefulness'. 'Lightness' refers not only to the work being "easy to transport and tour", but

\footnotetext{
${ }^{2}$ In a different context, Wei describes Grass Stage in contrasting terms as performing a 're-materialisation' of the stage. This is said to occur when intermediality - created by the use of projection and recorded music - is combined with the 'communal memory' of a non-theatre space (see Wei).
} 
also to Smith's purpose "to entertain and engage an audience rather than be argumentative or aggressive". 'Theatreness' suggests a reflexive quality, pursuing "an experiential heightening of the practice and reception of theatre itself', whereas 'togetherness' acknowledges the spectators' commitment to the live event as an enabler of agency. As a complement to the above, 'presentness' binds the work to the 'here and now', even though other scenarios are conjured up through storytelling, and 'hopefulness' fosters "a connection between thought and action". Smith reviews these five guiding principles via two of his monologues, the British-Norwegian commissions all that is solid melts into air (2011) and commonwealth (2012).

\section{Beyond Representation?}

Reiterating political theatre's attentiveness to what happens beyond stage and auditorium, Smith is keen for the audience "to see what occurs in the theatre as part of the world rather than as something separate from it", yet at the same time he avoids "trying to represent aspects of our life and society realistically". While Smith makes a distinction between his concept of 'presentness' and that of 'presence', about which he has some reservations, the latter is invoked in relation to other practitioners discussed in this section. González Ortiz explains the 'literalism' of La Re-sentida in terms of their desire to present on stage not "a symbol of an aspect of reality but [...] a reality in its own right", Pesti describes NO99's aesthetics as "an eclectic mix of representational and non-representational styles" and Wei quotes Zhao Chuan - director of Grass Stage - stating that the company's methodology "is not representation [of social life], but infiltration and interference on a real level". 3 The dichotomy of 'representation' versus 'presence' has indeed been paramount to new interpretations of the political in the wake of Hans-Thies Lehmann's influential 1999 treatise Postdramatic Theatre (translated into English in 2006). Florian Malzacher summarises the argument as follows:

At the centre of the critique of dramatic theatre stood its use of however estranged mimetic representation, which was seen as discredited and was subsequently confronted with the notion of presence. [...] Instead of representing a (fake) situation in order to

\footnotetext{
${ }^{3}$ However, both Pesti and Wei do not fully discard the use of metaphor as part of an array of resources that, on the whole, align NO99 and Grass Stage with the postdramatic paradigm. Wei characterises Grass Stage as "combining physical theatre, postdramatic text, documentary theatre, multimedia installation and spectatorperformer interaction".
} 
critique it the aim was to create a (real) situation in the co-presence of the audience, focusing on the here and now of the experience. (18-19)

This critique of representation is twofold, regarding both the artistic and the political meaning of the word. In the former sense, mimesis ceases to be trusted when the 'real' is no longer perceived as stable or, as Karen Jürs-Munby puts it in her introduction to Lehman's eponymous book, "postdramatic theatre has [...] not given up on relating to the world but crucially no longer represents the world as a surveyable whole" (12). In the latter sense, "the questions that currently haunt all democracies - who is being represented in which way by whom and with what right? - are mirrored in theatre" (Malzacher 24; see also González Ortiz in this volume). The first objection, to representation as mimesis, will be examined in the segment below, so let us probe the second here. Although Malzacher considers pluralism the only way forward, he recognises that strategies of "self-representation", such as 'real people' replacing professional performers or actors playing themselves ${ }^{4}$ may end up with "respect for 'the other' $[\ldots]$ turned into either its fetishisation or into the self-centredness of believing one's own living room to be the world" (25).

In her recent article "A Victory for Real People: Dangers in the Discourse of Democratisation", Liz Tomlin elaborates on the limitations of this particular practice, most often associated with Berlin-based company Rimini Protokoll and their use of so-called 'experts of the everyday', ${ }^{5}$ but which she also sees as a reflection of the political climate surrounding the UK vote to leave the European Union in 2016. As well as highlighting the risks of "exoticisation" and "voyeurism" involved in treating class difference as an unspoken assumption in the performance of 'real people' (“A Victory" 237), Tomlin draws attention to the "ideological scripts" concealed behind the apparent authenticity of these voices, scripts that are in fact "written by experts, whether or not the experts care to show their hand" (247). Within Hamidi-Kim's taxonomy of contemporary definitions of political theatre, this type of documentary work pertains to the realm of the 'post-political', which she characterises as a

\footnotetext{
${ }^{4}$ Either of - or both - these strategies feature in the work analysed by all contributors to this section, with the notable exception of Smith, whose (predominantly 'solo') practice is based on fictional storytelling. See also Boll in Part 1 for a politically potent example of self-testimony on stage.

${ }^{5}$ Tomlin traces this 'discourse of democratisation' to Lehman and includes one of Rimini Protokoll's projects among other examples of participatory and verbatim theatre. Also, drawing on Ulrike Garde and Meg Mumford, Tomlin identifies the two sides of the move away from representation mentioned above - that is, 'real people' are both "people that are not fictional characters, and people that are not theatre professionals" (Tomlin, "A Victory" 237).
} 
rather nihilistic strand that recycles old radical theatre forms "from which all political potential has been scooped out".

There is another way in which the postdramatic displays its supposed democratic credentials. As Pesti argues in this volume, the non-hierarchical arrangement of different components in postdramatic performance is perceived as giving audiences greater interpretive freedom. A similar observation, however, has been made with regard to contemporary nonrealist (but still dramatic?) plays by virtue of what Vicky Angelaki calls "the core dramaturgical device of stories in formation" (3). In other words, "we are in a space of exchange where we are called to think, question, judge and be moved rather than consume a politically gratifying message that might reaffirm any given spectator's ideological or intellectual superiority" (Angelaki 3). Both these persuasive claims seem to correspond with the anti-mastery Rancièrian approach to art and spectatorship, which is also how Smith frames his effort to facilitate a "humble" relationship between the stage and the audience. Smith follows Rancière in challenging the traditional understanding of viewing as inherently passive, supporting instead the philosopher's statement that "[t]he spectator also acts" (Rancière 13). In consequence, rather than opting for immersive settings or the aforesaid performance of 'real people' in order to, presumably, 'activate' the audience, Smith relies on the simplicity of the black box space.

A related but more provocative hypothesis by Rancière concerns the alleged 'efficacy' of art, where he criticises discourses that cling to what he considers a naïve and outdated pattern:

We may no longer believe that the exhibition of virtues and vice on the stage can correct human behaviour. But we are still prone to believe that the reproduction in resin of a commercial idol will make us resist the empire of the 'spectacle' or that the photography of some atrocity will mobilize us against injustice. Modern or postmodern as we purport to be, we easily forget that the consistency of this model was called into question as early as the 1750s. (61)

This guarded stance, which only acknowledges "a paradoxical kind of efficacy that is produced by the very rupturing of any determinate link between cause and effect" (63), has had a remarkable impact on theatre scholarship. As a case in point, Głowacka’s contribution to this section also calls upon Rancière when discussing Strzępka and Demirski's reluctance to attribute "causal power" to their work. Yet the Rancièrian outlook has not been free from 
scrutiny. For instance, Malzacher's assertion that "[c]omplexity can become an excuse for intellectual and political relativism" points to the problematic side of Rancière's "scepticism towards any clear political statement in art and his valorising of the power of ambiguity and rupture" (20). Moreover, to what extent form itself can be deemed political and whether nonexperimental theatrical forms should be excluded from such categorisation are matters of intense debate, as the next segment will demonstrate.

\section{The Politics of Form}

The postdramatic turn in theatre studies has also promoted an emphasis on form against content as the decisive factor that makes stage material 'political'. For Lehmann, "It is not through the direct thematization of the political that theatre becomes political but through the implicit substance and critical value of its mode of representation" (178). This indicates, as the introduction to the collection Postdramatic Theatre and the Political: International Perspectives on Contemporary Performance spells out, that the "modes of political engagement" of the postdramatic "are significantly different to what has previously been considered "political theatre"” (Carroll et al. 1). Brandon Woolf remarks in the same volume that this analysis has now extended beyond academics "concerned only with the postdramatic", noting that "[i]n place of the content-based 'political theatre', critics have begun to explore theatre's (negative) political potential as much more indirect, much more unpredictable" (44). Perceptively, Woolf detects here the influence of Frankfurt School thinker Theodor Adorno.

Grochala's reconceptualisation of the political play serves to illustrate Woolf's point. Although she is not dealing directly with postdramatic practices and despite proposing the multifaceted description quoted at the beginning of this introduction, her book sanctions the privileging of form above all other aspects. She declares that "a political play is not necessarily a play that addresses a political issue; rather, it is a play that opens the audience's eyes to how the world could be different" (22) and concludes the paragraph with a citation from Adorno. An alternative view, however, can be found once again in Tomlin, whose 2013 monograph Acts and Apparitions: Discourses of the Real in Performance Practice and Theory (1990-2010) attempts to dismantle the "ideological opposition" between the dramatic and the postdramatic (9). Tendering a word of caution on the Adornian claim "that aesthetic form can offer radical political transgression, regardless of the specific content or context of the work" (Acts and Apparitions 48), Tomlin expresses reasonable doubts on what may have become a new orthodoxy. She writes, "the conclusive alignment of ideological characteristics 
on the basis of form alone is ultimately self-defeating, and destructive to the future development of new strategies and contexts in which radical models of performance, and their relationship with ever-changing notions of 'the real', can be conceived" (12).

According to Woolf, the connection between Adorno and Lehmann sustains the latter's complex critique of mimetic representation, since "[m]imesis, for Adorno, does not consist of a dutiful copying of reality, a subsumption of the aesthetic by the real" (41). On the contrary - continues Woolf in a formulation close to Grochala's - "[b]y refusing to imitate the administered world, [art] indicates the possibility, albeit negatively, of another world that is not yet here" (42). However compelling this may sound as a manifesto, the potential exclusionary effects for the theory and practice of political theatre underlined by Tomlin cannot be ignored. Furthermore, as she has pointed out elsewhere with specific reference to political playwriting in Britain, such a position would bring about the unwarranted dismissal of "the broadly realist work of black dramatists such as Roy Williams and Kwame KweiArmah whose theatre might be argued to deconstruct and challenge, not primarily the dominant aesthetic form of the dramatic model, but the predominantly white and Eurocentric ownership of all its various [past] manifestations" (Tomlin, "Foreword" x).

A similar apprehension about the wholesale discrediting of realism has been articulated from a feminist perspective by Elaine Aston, who advises that in the "increasingly reactionary, neoliberal climate" that has prevailed so far in the twenty-first century, "a more inclusive approach is $[\ldots]$ needed to understand how socially progressive interests, feminist or otherwise, are being addressed in theatre and performance". Drawing on Raymond Williams's "Lecture on Realism" from 1977, Aston stresses that "the political impulse or dynamic within any dramatic form is conditioned by the socio-political pulse" and, therefore, "[c] ontext and form, not form alone, coordinate the political fabric of the drama" (19). Within this framework, she focuses on three plays by women that premiered at London's Royal Court between 2007 and 2012, Fiona Evans's Scarborough, Lucy Kirkwood's NSFW and Anupama Chandrasekhar's Free Outgoing. All three, for Aston, provide “"more fluid” applications of realism [that] reflect a shift away from those conservatively formed, phallocentric uses of the genre that were previously the object of feminist criticism" (32).

While Aston notices a heterogeneous contemporary realism, which she terms 'viral' so as to emphasise "its capacity for genetic mutation" (33), Grochala queries the ability of the foundational political play - "a play that yokes together the dialectical discussion of a political issue with a realist dramaturgy" (13) - to adapt and retain its progressive character in the present. Grochala builds on Zygmunt Bauman's diagnosis of a 'liquid' phase of 
modernity to depict our time as one of "insecurity, uncertainty and unsafety" (16) to which only equally 'liquid dramaturgies' can do justice. ${ }^{6}$ In such conditions, she contends, the paradigm of 'serious drama', which has served as a blueprint for political theatre in Britain ever since its inception in the late nineteenth century through the work of George Bernard Shaw, becomes reactionary:

The structures of serious drama reproduce structures that are associated with solid modernity and as such they are inadequate to capture the complex and ever-shifting social structures of liquid modernity. Serious drama can offer a critique of current political issues in its content and offer imaginary resolutions to these problems through dialectical discussion, but by reproducing rational representations of social structures through its dramaturgy, serious drama misrepresents the complex mechanisms that underlie the process of thinking, planning and taking action in a globalized society. (Grochala 219)

Although the contemporary viability of the Shavian model has been disputed many times before (see, for instance, Grimes), the reverse is also the case. In an article published in 2014, Ellen Redling salutes the rise of a new crop of British 'plays of ideas' typified by "discussion" over action and the tackling of "larger issues" instead of micro-narratives (160). Redling places this development within the context of a revival of "deliberative democracy" in the West, with deliberation understood as "ordinary people thinking for themselves rather than handing over responsibilities to others unquestioningly" (161).

In light of such conflicting arguments, it might be wise to take another look at Aston's choice of adjective and wonder whether it is possible that more 'fluid' versions of previous political theatre forms could be deployed to suit the demands of today. Perhaps this is exactly what González Ortiz's account of La Re-sentida's play La imaginación del futuro (Imagination of the Future, 2013) shows: in an analysis inspired by Bauman as well, twentyfirst century politicians portrayed in 'liquid' mode coexist with a 'solid' assessment of Chile's unreformed social and economic system. Bauman's theory of late modernity is also cited by Wei regarding China's rapid transformation and by Smith on the damaging effects this 'liquid' environment has on individual agency. That Smith's 'life-size' dramaturgy - a very different proposition to the plays examined by Grochala - responds directly to the deficit

\footnotetext{
${ }^{6}$ Summarising rather crudely, Grochala's 'liquid dramaturgies' encompass simultaneous time, virtual and layered spatial arrangements, indeterminate plots and subjectively constructed characters.
} 
in social solidarity which concerned Bauman attests to the multifarious nature of current political theatre, where prescriptions are likely to be counterproductive.

\section{The Politics of History}

As depicted by Hamidi-Kim, the aforesaid notion of the 'post-political' is informed by postmodernist philosophy and an accompanying conception of history as "no longer [...] moving ahead towards a better future but forever bogged down in an everlasting present that keeps repeating itself". However, there is evidence to suggest that contemporary culture is stepping beyond this milieu. For Siân Adiseshiah and Louise LePage, "detectable markers" of such a shift include "a revival of belief, a rehabilitation of agency and [as mentioned above] a (re)turn to realism" (4). A fresh engagement with history is also afoot, which at least in Britain has resulted in the proliferation of new plays set in the past that - as Brechtian 'historicisation' advocates - concomitantly explore the present. As I have argued, the twentyfirst-century history play can be said to "combine 'metahistorical' reflexivity with key aspects of the radical/oppositional/revisionist model", enacting a synthesis between contemporary and earlier traditions of political theatre. Therefore, "[w]hile the suspicion over received historical wisdom remains a core feature, the alternative provided is a set of questions and/or possible directions rather than the certainty offered by modern teleologies" (Botham 89).

History is pivotal to the stage work addressed by Głowacka, Pesti, González Ortiz and Wei in this section. Strzępka, Demirski and Klata in Poland, Theatre NO99 in Estonia and La Re-sentida in Chile fuse an acerbic critique of national(ist) narratives - especially those of a mythical heroic past - with innovative dramaturgies that are not afraid of fictionalisation and/or parody, whereas Grass Stage's World Factory connects globalised China today to industrial Manchester in the nineteenth century. At the same time, the very history of political theatre is revisited in these case studies, with current practitioners injecting new life into old forms. Głowacka travels as far back as ancient Greece to unearth a tradition of popular comedy that, continuing through Polish cabaret into contemporary performance, has not lost any of its bite. In a similar vein, González Ortiz finds in the figure of the fool or bouffon the perfect antecedent to La Re-sentida's aesthetics of 'excess', with clowning also being at the centre of the Grass Stage devised routines described by Wei. Pesti spots a tension between the legacy of Bertolt Brecht and the postdramatic turn ${ }^{7}$ in the aims and style of Theatre NO99

\footnotetext{
${ }^{7}$ See Barnett for a meticulous study of the differences between the 'post-Brechtian' and the postdramatic.
} 
and Smith returns to storytelling for his 'dematerialised' practice. Meanwhile, the scheme formulated by Hamidi-Kim in the opening chapter, where four definitions of political theatre compete for our attention, is a healthy reminder that parallel understandings of artistic practice can and do exist simultaneously, even if recognition is always selective.

As I conclude this third and final introduction to the volume, I would like to consider yet another angle to the historical dimension by recalling Steve Tillis's defence of 'world theatre history' as "a more or less integrated view of theatre history in multiple regions of the world", which "encourages [...] linkages that derive both from actual contact and from aesthetic similarity" (389-90). In framing the individual chapters brought together in this collection we have attempted such an exercise of integration without imposing a preset editorial agenda. That is to say, the architecture - and geographical scope - of this book responds to the actual conversation of the Political Performances Working Group in its second decade of existence, rendering found synergies as genuine instances of cultural interaction. Another aspect of this conversation has always been a two-way transit between academia and theatre practice, and this is why both parts of the present anthology end with the reflections of a practitioner over what it means to create political theatre and performance today.

\section{Works Cited}

Adiseshiah, Siân, and Louise LePage. "Introduction: What Happens Now." Twenty-First Century Drama: What Happens Now, edited by Siân Adiseshiah and Louise LePage, Palgrave Macmillan, 2016, pp. 1-13.

Angelaki, Vicky. Social and Political Theatre in $21^{\text {st }}$-Century Britain: Staging Crisis, Bloomsbury Methuen Drama, 2017.

Aston, Elaine. "Room for Realism?” Twenty-First Century Drama: What Happens Now, edited by Siân Adiseshiah and Louise LePage, Palgrave Macmillan, 2016, pp. 17-35.

Barnett, David. "Performing Dialectics in an Age of Uncertainty, or: Why Post-Brechtian $\neq$ Postdramatic." Postdramatic Theatre and the Political, edited by Karen Jürs-Munby et al., Bloomsbury Methuen Drama, 2013, pp. 47-66.

Botham, Paola. "The Twenty-First-Century History Play." Twenty-First Century Drama: What Happens Now, edited by Siân Adiseshiah and Louise LePage, Palgrave Macmillan, 2016, pp. 81-103. 
Carroll, Jerome et al. "Introduction: Postdramatic Theatre and the Political." Postdramatic Theatre and the Political, edited by Karen Jürs-Munby et al., Bloomsbury Methuen Drama, 2013, pp. 1-30.

Fişek, Emine. "Palimpsests of Violence: Urban Dispossession and Political Theatre in Contemporary Turkey.” Comparative Drama, vol. 52, nos. 3 and 4, 2018, pp. 349-71.

Grimes, Charles. "Bernard Shaw's Theory of Political Theatre: Difficulties from the Vantages of Postmodern and Modern Types of the Self." Shaw, vol. 22, 2002, pp. 117-30.

Grochala, Sarah. The Contemporary Political Play: Rethinking Dramaturgical Structure, Bloomsbury Methuen Drama, 2017.

Jürs-Munby, Karen. "Introduction.” Postdramatic Theatre, by Hans-Thies Lehmann, translated by Karen Jürs-Munby, Routledge, 2006, pp. 1-15.

Lehmann, Hans-Thies. Postdramatic Theatre. Translated by Karen Jürs-Munby, Routledge, 2006.

Lipovetsky, Gilles. Hypermodern Times. Translated by Andrew Brown, Polity, 2005.

Malzacher, Florian. "No Organum to Follow: Possibilities of Political Theatre Today." Not Just a Mirror: Looking for the Political Theatre of Today, edited by Florian Malzacher, House on Fire, Live Art Development Agency and Alexander Verlag, 2015, pp. 16-30.

Rancière, Jacques. The Emancipated Spectator. Translated by Gregory Elliott, Verso, 2009.

Redling, Ellen. "New Plays of Ideas and an Aesthetics of Reflection and Debate in Contemporary British Political Drama." Journal of Contemporary Drama in English, vol. 2, no. 1, 2014, pp. 159-69.

Sauter, Willmar. "Introducing the Theatrical Event." Theatrical Events: Borders, Dynamics, Frames, edited by Vicky Ann Cremona et al., Rodopi, 2004, pp. 3-14.

Tillis, Steve. "The Case against World Theatre History." New Theatre Quarterly, vol. 28, no. 4, 2012, pp. 379-91.

Tomlin, Liz. "Foreword: Dramatic Developments." Contemporary British Theatre: Breaking New Ground, edited by Vicky Angelaki, Palgrave Macmillan, 2013, pp. viii-xxvi.

---. Acts and Apparitions: Discourses of the Real in Performance Practice and Theory (19902010), Manchester University Press, 2013.

---. “A Victory for Real People: Dangers in the Discourse of Democratisation.” Journal of Contemporary Drama in English, vol. 6, no. 1, 2018, pp. 234-48. 
Wei, Zheyu. "Re-Materialising the Theatrical Public Sphere Through Intermediality in Grass Stage's World Factory." Intermedial Performance and Politics in the Public Sphere, edited by Katia Arfara et al., Palgrave Macmillan, 2018, pp. 209-27.

Woolf, Brandon. “Towards a Paradoxically Parallaxical Postdramatic Politics?” Postdramatic Theatre and the Political, edited by Karen Jürs-Munby et al., Bloomsbury Methuen Drama, 2013, pp. 31-46. 